\title{
Gorazd Kovačič \\ Michel Freitag: \\ Brodolom univerze in drugi eseji iz politične epistemologije
}

Ljubljana: Sophia, 2010, 327 strani

Knjigo Brodolom univerze in drugi eseji iz politične epistemologije švicarskokanadskega sociologa Michela Freitaga (1935-2009) sestavlja več razprav, povezanih z jasno rdečo nitjo. Vsebine te rdeče niti ne izraža toliko glavni del naslova, »Brodolom univerze«, temveč bolj njegov dodatek. Freitag razvija argumentacijo v prid politične prenove epistemologije družboslovja oziroma se zavzema za premik od scientistične epistemologije, v katero je zašlo in v njej nasedlo družboslovje 20. stoletja, k politično ontološki epistemologiji. To pomeni, da bi moralo družboslovje svojo epistemologijo ponovno utemeljiti na normativni transcendenci in se $s$ tem izvleči iz svoje "postmoderne« ujetosti v tehnološki in aplikativni pristop. Glavnina knjige se ne posveča toliko brodolomu univerze (kar je le izhodišče razprave), temveč predvsem zgodovinskemu razvoju družboslovja, njegovemu brodolomu in nalogam v sedanjem položaju.

V teoretskem smislu Brodolom univerze prinaša za tukajšnji intelektualni prostor nekoliko nenavadno, a vsekakor konsistentno kombinacijo heideggerjanskega in arendtovskega eksistencialističnega pristopa, durkheimovske teme družbene integracije ter zaključkov, ki korespondirajo s sodobno historično materialistično kritiko kapitalizma, ideologije in znanosti. S pomočjo te teoretske kombinacije Freitag artikulira koncept družbe, ki je njegova osrednja problematika, iz katere izpelje analizo aktualnih zgodovinskih prelomov ter položaja družboslovja in univerze. Da bi razumeli, kam Freitag meri s tezo o brodolomu univerze in družbenih znanosti, se moramo osredotočiti na njegov koncept družbe.

Freitagov koncept družbe je normativen in meri na to, kako naj bi ljudje idealno ravnali. Izhaja iz antropološke izhodiščne teze, da ljudje kot intersubjektivna in svetna bitja delujejo ter sebe in svet dojemajo skozi normativne sheme. Freitag trdi, da brez norm sploh ne bi mogli misliti in ne bi ničesar razumeli, niti stvari in drugih bitij v skupnem svetu niti samih sebe. Normativnost je "prvotni ontološki način vsake subjektivne eksistence« (str. 132), kar 
pomeni, da bitje svoje ravnanje v svetu usmerja $z$ lastnimi smiselnimi odločitvami. Da bi ljudje lahko mislili, potrebujejo skupno simbolno oziroma normativno totalnost - in ta je prav družba.

Družba je po Freitagu »totalnost subjektivnega značaja« (str. 159), ki jo imajo ljudje v mislih, kadar mislijo in delujejo. Družbenost je »odnos do drugega, apriorno posredovan s skupno pripadnostjo [normativni] totalnosti« (str. 174). »'Družbeno življenje' tvorijo simbolno posredovana subjektivno pomenjujoča dejanja, normativno urejena v 'družbene odnose', ki so hkrati konkretno objektivni (kategorični in strukturni) in (inter)subjektivni. [...] Referenca na neki skupni simbolni sistem [je] tista, ki usmerja posamezna dejanja in jih nekako iz notranjosti vsakega izmed njih integrira v neko splošno strukturo« (str. 159).

Tradicionalnemu razcepu sociologije na strukturalizem in (mikro)perspektivo delovanja oziroma na strukturno determiniranost in fenomenološki opis subjektivnih procesov monade Freitag zoperstavi koncept kontingentnosti. Z njim hoče povedati, da potek človeške zgodovine ni rezultat naključij ali samodejnega uresničevanja določenih zakonitosti, temveč refleksivnega in avtonomnega delovanja, ki pa je vedno vpeto $\mathrm{v}$ določeno družbeno tradicijo. Kontingentni način biti ne sledi »zunanjim in objektivnim ('nujnim') 'zakonom', temveč notranjim normam« (str. 180), ki pa so skupnostne. Freitag potemtakem stavi na odgovornost, ki izhaja iz zmožnosti mišljenja, in izrecno nasprotuje psevdonaturalističnemu fatalizmu, ki bi človeka pojasnjeval kot »skupek reakcij« (Arendt).

V jedru Freitagovega koncepta družbe sta dejstvo mišljenja in zaveza k mišljenju. Družba ni le imaginarij posameznih človeških bitij, ki brez njega ne bi zmogla misliti. Ker se mišljenje vedno že odvija v nekem skupnem prostoru in ker je do določene mere skupna dejavnost, je družba tudi mesto in realni subjekt kolektivne samorefleksije. Za razumevanje avtorjevih aktualnih sodb o »družbenem življenju«, »družbenih « vedah in univerzi je ključno naslednje: družba je po definiciji nekaj, kar misli sebe, kar je samorefleksivno. Če se ne zmore misliti, če ne izvaja samorefleksije, potem ta način bivanja ljudi ni več družba, temveč postane nekaj drugega.

$\mathrm{V}$ predmodernih družbah so ljudje sicer mislili družbeno, vendar pa niso uzavestili družbe kot take, temveč so svojo skupno normativno referenco projicirali v posvetne ali sakralne avtoritete. Šele v moderni dobi so se zavedli, da je tisto, kar jim daje normativni temelj, družba. Pri tem so jim odločilno pomagale družbene vede, ki so si zadale nalogo »osmisliti družbo za družbo in v njenem imenu«, takrat ko religija in druge instance tega niso več zmogle. Temeljno normativno referenco so našle $\mathrm{v}$ sami »funkcionalni soodvisnosti 'družbenih dejstev'« (str. 182). 
Toda v sodobnem postmodernem svetu sta po Freitagu vsakršna normativno posredovana enotnost in smiselnost bivanja razpadli. Enotni družbeni horizont se je umaknil tehnokraciji, za katero je značilna na eni strani odsotnost osmišljajoče refleksije, na drugi strani pa fragmentacija vplivanj in upravljanj. Avtor navaja naslednje modalitete bivanja $\mathrm{v}$ tehnokratskem svetu: nereflektiranost, kalkuliranje, programiranje, procesnost, fragmentacija, obvladovanje medsebojno ločenih polj prek produkcije in pragmatičnega upravljanja s serijami spremenljivk, reakcij in regularnosti; z eno besedo: sistem. Dejavni subjekti sistemskih procesov po Freitagu niso več individualne ali kolektivne osebe z univerzalno zavestjo (družbe, države itd.), temveč korporacije, organizacije, mreže, sistemi. Ti si prizadevajo za »učinkovitost, ne za vrednote, resnico in smotre (str. 123-124). Freitag torej prikazuje vrednostno oster razloček med smisla polno družbenostjo, ki je odlikovala še moderno dobo, pa tudi predhodne tradicije, in med smisla oropanim bivanjem pod foucaultovsko neosebno socialno tehnološko vladavino.

Regresija od družbene zavesti $\mathrm{k}$ tehnokraciji je po Freitagu značilna tudi za procese $\mathrm{v}$ družboslovju in na univerzi $\mathrm{v} 20$. stoletju. Moderno družboslovje je od predznanstvenih oblik družbene samorefleksije prevzelo normativno idejo družbe ter jo napolnilo s progresizmom in racionalizmom kot posebno moderno vsebino. Moderno družbo je pojmovalo kot subjekt integracije in univerzalnosti, svoj lastni prispevek pa je videlo $\mathrm{v}$ pedagoškem usmerjanju družbenega življenja $\mathrm{v}$ smeri umnega. Dokler je moderna družba, kot se je zdelo družboslovcem, delovala racionalno (oziroma dokler se je družboslovcem, slepim za krivice na obrobju »družbenega razvoja«, zdelo, da družba deluje racionalno), sta jim njihov progresizem in instrumentalni racionalizem preprečevala, da bi uzrli nasprotje med normativnim poslanstvom družbenih ved in njihovo ambicijo po uporabi eksaktnega razlagalnega aparata in po empirični ustreznosti. Zdelo se je, da družbene vede $\mathrm{v}$ empirični družbeni realnosti najdevajo tisto normativno načelo (racionalnost, umnost), ki ga tudi sicer hočejo afirmirati.

Ko pa je v realnosti zavladal režim socialnih tehnik in je pragmatizem zamenjal celostne normativne legitimacije, so tudi družbene vede opustile velike normativne pripovedi in se sprevrgle $\mathrm{v}$ socialne tehnike, ki se ponujajo tehnokratskemu upravljanju. Tehnokratska revolucija $\mathrm{v}$ znanostih se je zgodila tako na ravni temeljev (opustitev ontologije $\mathrm{v}$ prid tehnični epistemologiji, ki človeški svet spoznavno drobi na vrsto ločenih sektorjev, razpoložljivih za ekspertno znanje in upravljanje) kakor tudi na ravni raziskovalne politike (paradigma policy). Splošni problem integracije, ki se mu je posvečala moderna sociologija, se je umaknil »množici lokalnih oziroma sektorskih problemov družbene integracije posameznikov, skupin ali kategorij« (str. 97), pri čemer se je veda fragmentirala v množico specialističnih empiričnih študijev 
s tehnološko metodologijo, ki se osredotoča predvsem na predvidljivost učinkovanja. Isto velja za regresijo ekonomske znanosti v menedžment.

Kadar je tehnično družboslovje vpeto $\mathrm{v}$ mehanizme tehnokracije, nastopa kot sredstvo za produkcijo »družbe«. Toda ta »družba« ni več freitagovska družba normativne refleksije, temveč Freitag ( $v$ slovenskem prevodu Katje Kraigher) to nepregledno in brezumno polje vplivanj in reakcij poimenuje $\mathrm{z}$ drugačnim izrazom: "socialno«. Moderno progresistično družboslovje in tehnizirane postmoderne »družbene« vede torej nimajo istega temeljnega spoznavnega predmeta. Še več: Freitag ocenjuje, da tehnizirane »družbene« vede, ki ne omogočajo več (normativnega) mišljenja, po svoji formi in smotru sploh niso več družbene.

Freitagov opis razpršenosti in instrumentalnosti »socialnega « izrazito črpa pri pesimističnem pogledu Hannah Arendt na moderno množično družbo, tudi pojem oziroma koncept »socialnega « si je izposodil pri njej, medtem ko je koncept »družbe« prevzel od Durkheima. Pri tem pa velja opozoriti, da pri Hannah Arendt razlike med »socialnim« in »družbo « pravzaprav ni, in to niti na ravni poimenovanja niti na ravni vrednotenja. V kompleksu sistemskega in neosebnega gospostva je Hannah Arendt videla prej nasledek kakor prekinitev $\mathrm{z}$ modernim holističnim diskurzom družbe. Vse tisto zaželeno, kar Freitag umešča v kategorijo »družbe« (integracija, umeščenost, sprejetost, smiselnost, pluralnost), Hannah Arendt zaobjema s kategorijo sveta. A bistvena razlika med avtorjema ni v premestitvi posameznih ključnih pojmov, temveč v tem, da Freitag svoje aspiracije po osmislitvi postmodernega življenja projicira v neki univerzalistični makrokoncept, medtem ko je Hannah Arendt takšne metanarative pod vtisom izkušnje zdrsa razsvetljenske civilizacije v šoo opustila. Poleg tega avtorja stavita na različni vrsti dejavnosti, ki naj omogoča preboj iz »upravljanega sveta« (Marcuse) oziroma ki ju je treba rešiti pred »vladavino tehnike« (Heidegger). Freitag poudarja predvsem refleksijo, torej neodvisnost in moč mišljenja, Hannah Arendt pa poleg mišljenja računa tudi z delovanjem. V tem smislu je Freitagova strategija eksistencialno smiselnega preživetja $\mathrm{v}$ tehnokratskem sistemu bolj heideggerjanska (umik v mišljenje) kakor arendtovska (uporno delovanje).

Medtem ko se Freitagova knjiga posveča predvsem »brodolomu družboslovja«, spremna beseda Rastka Močnika k slovenskemu prevodu dodaja izčrpno analizo položaja sodobne (slovenske) univerze kot institucije. V zvezi z možnostmi (ponovne) vzpostavitve akademske skupnosti kot skupnosti teoretskega dialoga pri nas je Močnik precej pesimističen, Freitag pa ne izgublja upanja ter univerzi in družboslovju nalaga teoretsko in pedagoško nalogo "vzpostavitve novega odnosa do vrednot « (str. 179). Pot tja ni epistemološka oziroma metodološka, temveč ontološka: gre za temeljno ontološko vprašanje biti družbe. To je projekt Freitagove knjige Brodolom univerze. 